\title{
Original research and the Mexican Journal of Ophthalmology
}

\section{La investigación original y la Revista Mexicana de Oftalmología}

\author{
Roberto González-Salinas ${ }^{1}$ and Manuel A. Garza-León ${ }^{2 *}$ \\ ${ }^{1}$ Associate editor; ${ }^{2}$ Editor-in-chief. Revista Mexicana de Oftalmología, Sociedad Mexicana de Oftalmología, Mexico City, Mexico
}

«Today's science is tomorrow's technology»

Edward Teller

Scientific thinking is essential to critically evaluate the deliberations around new knowledge, as well as to understand and make the most of research publications, so that we can practice ophthalmology on a solid foundation.

In this edition, the Revista Mexicana de Oftalmología publishes four original research articles, one of which deals with innovation in basic research. This article, sent by Dr. Zavala, et al. ${ }^{1}$ and entitled «Lipid and cholesterol metabolism gene expression in pterygium fibroblasts: comparative analysis with adipocytes and other fibroblasts", represents an example that reaffirms the impact and scope of basic research in ophthalmology in order to contribute to the characterization and knowledge of ocular diseases.

Through analogous research, the efforts of both basic and clinical science researchers have given rise to clinical trials aimed to prevent, treat and cure ocular diseases. The Revista Mexicana de Oftalmología, in this way, confirms its unwavering commitment to support original quality research, whose initiatives translate into advances in vision research, involving a direct and profound impact on patient care, through interdisciplinary approach of several fields of science, including biomedical engineering and medicine to make advances in visual science research, as well as in clinical ophthalmology.
We are enthusiastic to begin a new year for the Revista Mexicana de Oftalmología with high quality basic and clinical science articles. The articles selected for this issue were reviewed and chosen from original studies sent to journl consideration for publication, from several institutions in our country, Latin America and Europe, which makes us proud and therefore committed to promoting the strengthening and dissemination of scientific works in ophthalmology.

As we mentioned previously, on the first editorial of $2018^{2}$, the Revista Mexicana de Oftalmología applied to be included on the PubMed/MEDLINE index. To this regard, despite an improvement on key metrics compared to the previous application score in 2015 (3.5 vs. 3.0 points), the efforts failed to be enough to be included in this database. One of the topics needing improvement includes an escalation in both the quantity and quality of original research studies, as well as systematic reviews or meta-analysis. For this reason, we want to lay hold of this space to invite you to continue contributing to the advancement of the Revista Mexicana de Oftalmología through high-quality original studies.

In the last two years, the Revista Mexicana de Oftalmología has increased the number of articles received for consideration. In total, 195 articles were received during this period, with the support of the reviewers and the editorial committee, we have maintained a similar acceptance rate compared to the best ophthalmology journals in the world, aiming to provide our readers with

Correspondence:

*Manuel A. Garza-León

Miguel Hidalgo, 2425

Col. Obispado

Date of reception: 18-11-2018

C.P. 64060, Monterrey, N.L., México

E-mail: dr.manuel.garza@gmail.com

Date of acceptance: 20-11-2018

DOI: 10.24875/RMOE.M18000042
Available online: 11-01-2019

Rev Mex Oftalmol (Eng). 2019;93(1):1-2 www.rmo.com.mx

0187-4519/@ 2018 Sociedad Mexicana de Oftalmología. Publicado por Permanyer México. Este es un artículo Open Access bajo la licencia CC BY-NC-ND (http://creativecommons.org/licenses/by-nc-nd/4.0/). 
high-quality scientific information and to reflect the ophthalmology advancements in Mexico and in Latin America.

We hope to continue counting on your confidence while working to maintain and improve the scientific quality of our journal.

\section{References}

1. Zavala J, Treviño V, Reyna-Fuentes AA, Arellano-Gurrola CM, Enriquez-Ochoa D, et al. Expresión de genes del metabolismo de lípidos y colesterol en fibroblastos de pterigión: análisis comparativo con adipocitos y otros fibroblastos. Rev Mex Oftalmol. 2019;93(1):7-13

2. Garza-León M, González-Salinas R, Guerrero-Berger O, García-Águirre G. Un nuevo cambio, nuevas oportunidades. Rev Mex Oftalmol. 2018:92(1):5. 